\title{
Market trends and ethnobotany of orchids of Mount Cameroon
}

\author{
B. A. Fonge ${ }^{1 *}$, S. E. Essomo', T. E. Bechem', P. T. Tabot ${ }^{2}$, B. D. Arrey ${ }^{1}$, Y. Afanga ${ }^{1}$ and E. M. Assoua ${ }^{3}$
}

\begin{abstract}
Background: The Orchidaceae are noted for their floral diversity. In the Mount Cameroon Region (MCR), the genus Bulbophyllum is the most represented genus of the entire flora of this region. Despite the large number of different species in Orchidaceae, very little is known and documented about the orchids in Cameroon at large, in the MCR in particular. Orchids are widely used in flower gardens and trade. The aim of this study was to assess the floristic value of the orchids compared with those of other parts of the world and equally assess species which are used in herbal medicines.

Methods: This research was carried out in the MCR and the main flower market in Cameroon. Semi-structured questionnaires were administered to vendors, buyers, and cultivators at a ratio of 1:1:1, as well as to herbalists and cultural use indices computed. A total of 107 flower gardens in all gardening localities (07) of the region were sampled.

Results: A total of 66 out of 107 gardens had at least one orchid species. Five orchids which are hybrids cultivated by vegetative propagation are traded as ornamental plants in the MCR. A total of 23 species were used for herbal treatment of certain ailments. The ethnobotanical richness of orchids was scored at 6.86. Ansellia africana had the highest cultural importance index $(\mathrm{Cl})$, relative importance index $(\mathrm{RI})$, and the relative use index (RNU) while tradactyle tridactylites had the lowest. It was also found that most orchids were used for clairvoyance that is highly associated with myths or folklore and also for external application.
\end{abstract}

Conclusion: The level of awareness on uses of orchids in the MCR is low. Many people consume orchids mixed with different species of plants for herbal treatment. Orchid trade is used as a part of subsistence by orchid cultivators and vendors.

\section{Introduction}

While large populations of orchid are still found in their natural habitat, in many parts of the world, their number is decreasing due to high demand and population pressure. Many orchid species are threatened due to habitat destruction and indiscriminate collection [1]. At present, the orchids figure prominently in the Red Data Book prepared by the International Union for Conservation of Nature (IUCN), and the entire family was included in Appendix-II of the Convention on International Trade in Endangered Species of Wild Fauna and Flora (CITES) in 2017, where the international trade is regulated [1].

\footnotetext{
* Correspondence: ambofonge@yahoo.com

1 Department of Botany and Plant Physiology, Faculty of Science, University of Buea, P.O. Box 63, Buea, Cameroon

Full list of author information is available at the end of the article
}

Orchids are nature's extravagant group of flowering plants, distributed throughout the world from tropics to high alpine regions. They exhibit an incredible range of diversity in shape, size, and color of their flowers. They are important esthetically and medicinally and are also regarded as ecological indicators [2]. Many orchid species are cultivated for their various economic uses, especially in floriculture. Orchids are grown primarily as ornamentals and are valued as cut flowers because of their exotic beauty, and for most species, the flowers persist for long [3]. Some orchids are used as herbal medicines, food, and other cultural values by many different cultures and tribes in the different parts of the world [4].

Orchids are one of the largest and most diverse groups of angiosperms consisting of nearly 25,000 species with more than 850 genera $[5,6]$. The Orchidaceae are the second most diverse plant family in the Mount Cameroon 
Region after Asteraceae [7]. Some orchids like Eulophia campestris, Orchis latifolia, and Vanda roxburgii have drawn the attention of the scientific community because of their medicinal uses $[8,9]$. Medicinal orchids mainly belong to the genera: Calanthe, Coelogyne, Cymbidium, Cypripedium, Dendrobium, Ephemerantha, Eria, Galeola, Gastrodia, Gymnadenia, Habenaria, Ludisia, Luisia, Nevilia, and Thunia $[6,10]$.

Research has shown that Dendrobium spp., Gastrodium spp., and the hyacinth orchid (Bletilla striata) have been used in the treatment of ailments like hemorrhages of the stomach or lungs, uterine bleeding, and nose bleeds, as well as whooping cough [1], and more medicinal uses are being uncovered across the world [11].

However, in Cameroon, most studies of orchids have been centered mostly on inventory and diversity [12, 13], in spite of the various ways in which Cameroonians use orchids daily, and as a result, very little is known or published about the socio-economic importance and the ethno uses of orchids in Cameroon at large and the MCR in particular. This study therefore aimed at investigating ethnobotany of orchids of the Mount Cameroon Region, in view of bridging this knowledge gap. Specifically, the research addressed the following questions:

1. What orchids are of ornamental importance in the MCR?

2. What orchids have medicinal uses in the MCR and what are these uses?

In horticultural gardens in the MCR and a major market in Douala (Marche de Fleurs), orchids are among the most popular ornamentals traded. We theorized that this orchid trade is fueled by indigenous ornamental and ethnobotanical uses that justify the need for their conservation.

\section{Materials and methods Study sites}

The Mount Cameroon Region as shown in Fig. 1 is situated in the South West Region of Cameroon in Central Africa. The area extends from the Atlantic coast to Mount Cameroon, with an altitude of $4100 \mathrm{~m}$ [14]. Mount Cameroon is the highest mountain in West and Central Africa and an active volcano $[15,16]$. Due to the volcanic origin, the surrounding soil is rich in nutrients and provides high fertility for both natural vegetation and farmland [17]. The area has a humid tropical climate modified by the topography from sea level to the top of the mountain. The annual rainfall in most of the region ranges from 2500 to $3500 \mathrm{~mm}$, except at Debunscha, which is the wettest place in Africa with a mean annual rainfall of $10,000 \mathrm{~mm}$. The climate of the Mount Cameroon Region is predominantly tropical, with a dry season from November to February and a rainy season from March to October. Rainfall and temperatures diminish and are moderated up the slopes and further inland.

The mean annual temperature is about $25^{\circ} \mathrm{C}$ (Fraser PJ, Hall JB, and Healey JR: Climate of the Mount Cameroon Region: long and medium term rainfall, temperature and sunshine data, unpublished). The relative humidity remains at 75 to $80 \%$ throughout the year in the south-western side of the mountain, due to marine influence and the incidence of mist and orographic cloud formation.

\section{Socio-economic survey}

This survey was conducted to determine and record the ornamental uses of orchids. It was carried in various locations as follows:

For both surveys, three groups of persons were sampled; these include orchid cultivators, orchid vendors, and buyers. Mixed methods sampling was used in which respondents were identified through snowball sampling methods and data collected through semi-structured questionnaires, combining the rapid rural appraisal (RRA) and the participatory rural appraisal (PRA) approached. A total of 20 questionnaires were administered to each of the following groups: orchid vendors, cultivators, and buyers after obtaining oral Prior Informed Consent, giving a total of 60 interviews. Prior Informed Consent is sought from respondents to a study by explaining the purpose for the study and the personal liabilities of both the researcher and the respondent, and that the respondents can only participate willingly, retaining the right to withdraw from the study at any point is they so choose. This is done prior to each interview. The overall study was approved by the University of Buea Ethics Committee.

For the flower gardens, 107 flower gardens located at Mile 14 Dibanda, Mutengene, Bokwango, Likoko, Bwassa, and Sasse in the MCR were surveyed. The purpose of this survey was to record the type of orchid cultivated and sold as ornamentals.

The main flower market in Cameroon, known by its French appellation as "Le Marché des Fleurs" situated in Douala in the Littoral Region of the country, about $75 \mathrm{~km}$ from the study area was also surveyed to record the types of orchids sold and the cost price of respective species.

\section{Evaluation of medicinal potentials}

This study was carried out to discover the possible traditional medicinal values of orchids within the MCR. Herbalists and members of the population who had knowledge about the orchids were surveyed. A snowball sampling technique in tandem with a "show and tell" approach was used, whereby fresh plants and/or good photographs of plants were shown to respondents, followed by the 


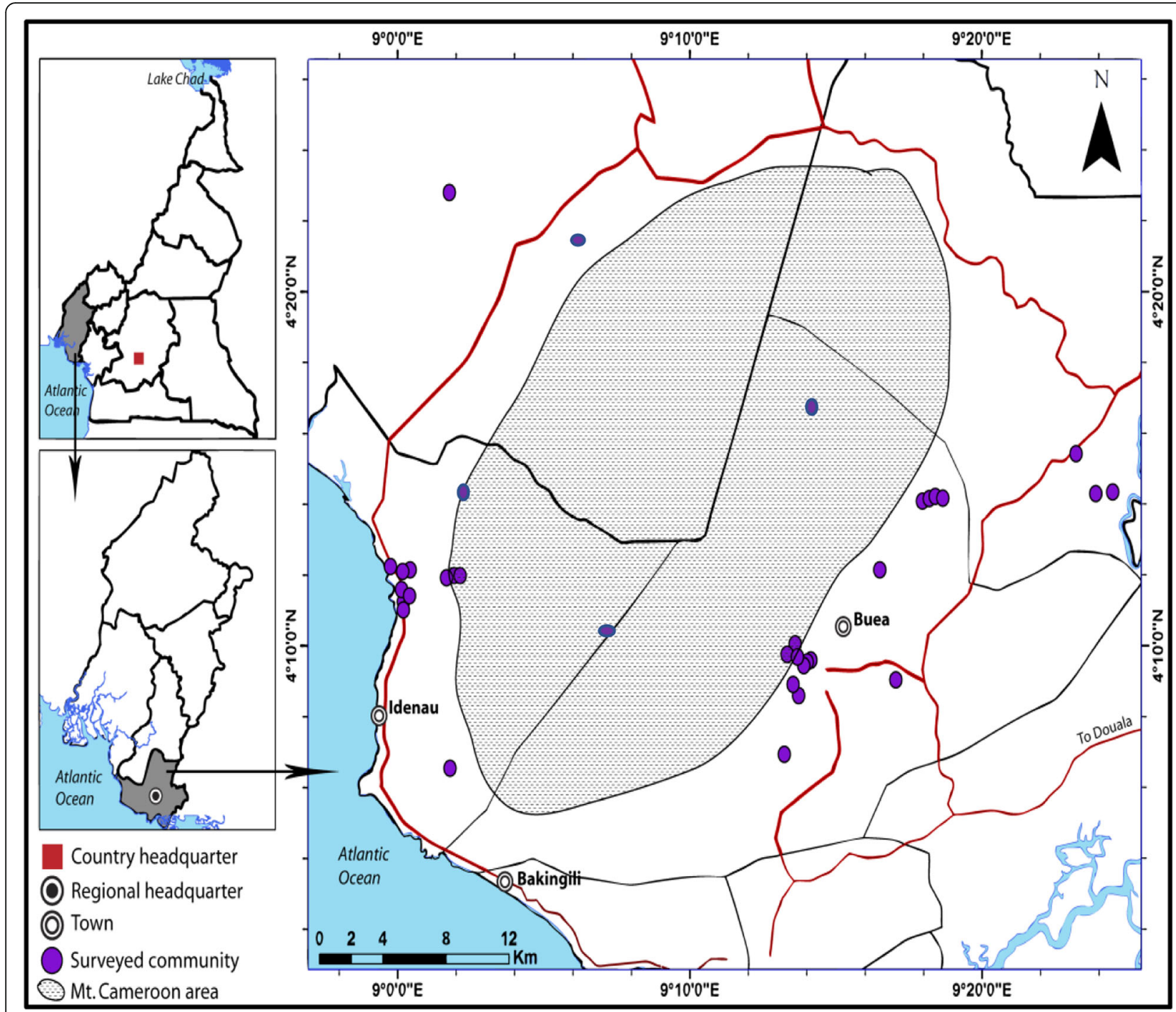

Fig. 1 The Mount Cameroon Region

questions about the plants. A total of 50 questionnaires were administered to these two groups of persons after obtaining oral Prior Informed Consent. Voucher specimens of all orchids collected were prepared and taken to the National Herbarium in Yaounde (YA) for identification and preservation.

\section{Data analysis}

The socio-economic values of orchids that determine their floristic or horticultural uses were analyzed using Microsoft Excel 2016 (Microsoft Inc., USA). Ethnobotanical data were categorized into 10 medicinal use categories namely: bone condition, skin conditions, epilepsy, stomach problems, psychological problems, reproductive, pulmonary conditions, clairvoyance, bloodrelated, and pains. Plants which are believed to be useful as charms with psychic powers were categorized under clairvoyance. These categories were modified from those of $[18,19]$. The basic variables like frequency of citation (FC), use reports (UR), number of uses (NU), and ethnobotanical indices such as the relative frequency of citations (RFC), relative importance index (RI), and cultural importance index $(\mathrm{CI})$ were determined using standard procedures as described in $[18,19]$.

\section{Results}

\section{Socio-economic survey}

\section{Distribution of orchids in flower gardens}

Of the 107 flower gardens that were surveyed in the MCR, 41 gardens did not have any orchid species while 66 gardens had at least one type of orchid species. Only a single garden out of the 5 visited in Sasse had an orchid species (Bletilla striata) (Table 1). Bletilla striata and Bletilla sp. were found in almost all the gardens in 
Table 1 Common names used in the study area

\begin{tabular}{llll}
\hline SN & Scientific name & Common name & Distinguishing names \\
\hline 1 & Papilionanthe teres $\times$ Papilionanthe hookeriana & Vanda Miss Joaquim & Leafless orchid \\
2 & Arachnis hookeriana var. luteola $\times$ Arachnis flos-aeris var. gracilis & Arachnis Maggie Oei yellow ribbon & Long stem orchid yellow flower \\
3 & Arachnis hookeriana var. luteola $\times$ Arachnis flos-aeris var. gracilis & Arachnis Maggie Oei red ribbon & Long stem orchid red flower \\
4 & Bletilla striata & Bletilla striata & Orchid pink flower \\
5 & Bletilla $\mathrm{sp}$. & Bletilla sp. & Orchid purple flower \\
\hline
\end{tabular}

Mile 14 Dibanda. Sasse, Bokwango, Likoko, and Clark's quarters had the least representation of orchid species, while Mile 14 Dibanda had the highest. Of the gardens that had orchids, Bletilla striata was present in all (Fig. 2). Mile 16 Bolifamba and Mutengene localities had all 5 orchids species while Bokwango, Likoko, Bwassa, and Clerks Quarter had only two each (Bletilla striata and Bletilla sp.). The Arachnis were found mostly in Mile 14 Dibanda and Mutengene, with a lone stand of the yellow ribbon found in a single garden in Bwassa.

There were 3 identified species in cultivation in the MCR and one identified to generic level. These included Papilionanthe teres $\times$ Papilionanthe hookeriana (Vanda Miss Joaquim), Arachnis hookeriana var. luteola $\times$ Arachnis flos-aeris var. gracilis (Arachnis Maggie Oei red and yellow ribbon), Bletilla striata, and another member of the genus Bletilla which could not be further identified in the course of the study. All orchid cultivators used one common name for the different orchids, "Orchidee." Table 2 indicates the common names used to distinguish the different orchids.

\section{Orchid trade}

The trade in orchids in the MCR and the main flower market in Douala is mainly fueled by the cut flowers market (horticultural values), and the prices vary depending on the species.
Arachnis Maggi Oei: Its peak marketing period is between December and February during which the prices are much elevated, as well as the months of July and August when the prices fall due to peak flowering periods. A single stalk (inflorescence) of this species is sold at 700 FCFA ( $\$ 1.25$ US) during the dry season and 500 FCFA (\$0.9 US) during the rainy season. All Arachnis sold in the flower markets were from the MCR. It should be noted that this species is grown by vegetative propagation and was not found in the wild. Florists who indulge its cultivation, from the start of flowering to the end, could have an average sale of approximately 250.000 FCFA ( $\$ 500$ US) per annum. Figure 3 represents a single day quantity of Arachnis brought by a flower vendor in the flower market during the month of February.

During this particular day (the weekend before Valentine's Day), a single inflorescence was sold at 1000 FCFA (\$1.7 USD). The total sale at the end of the day was 70.000 FCFA ( $\$ 125$ USD) per trader. It is worthy to note that Arachnis could flower as much as twice a year in favorable conditions. When found in a cool place and watered during the dry season, flowering could be induced. The general flowering period is during the rains from the months of July to August. The flowers are very easy to handle and could last from 2 weeks to a month after being cut off from the main plant depending on the storage condition. The red ribbon is often highly demanded than the yellow ribbon. These orchids are

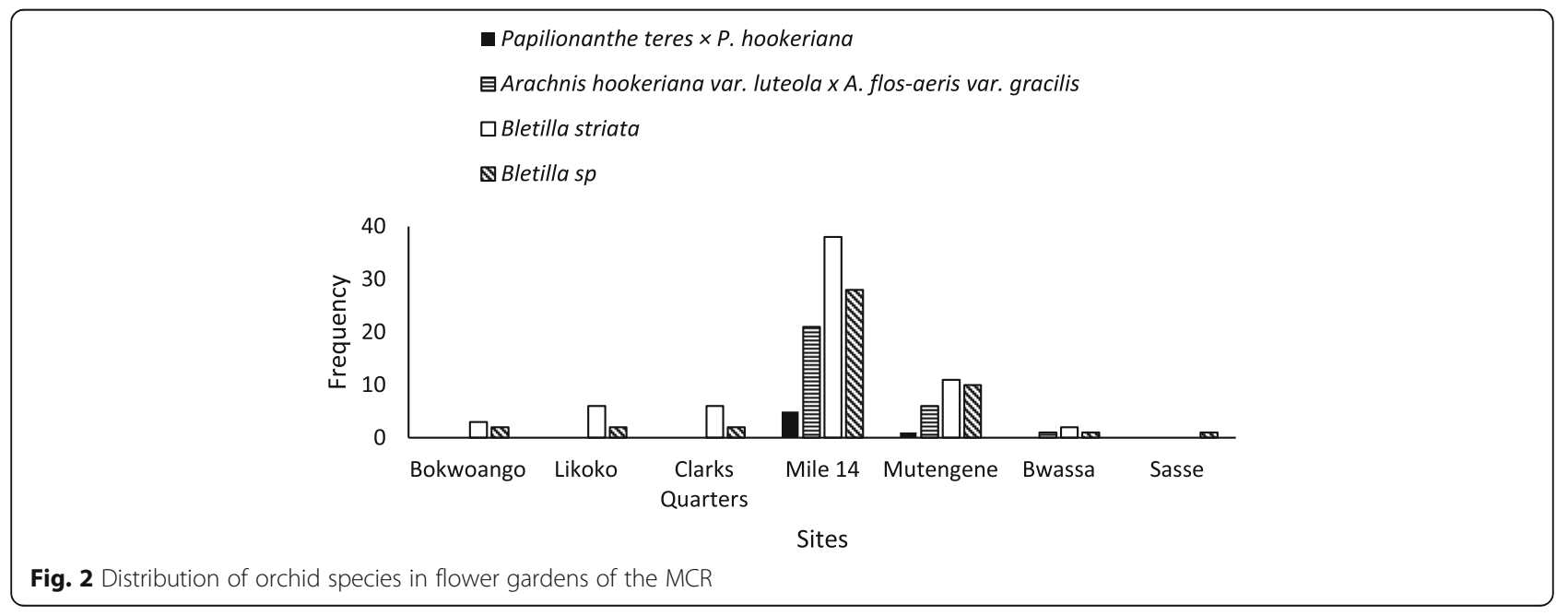


Table 2 Distribution of 5 orchids in flower gardens of the different localities of the MCR

\begin{tabular}{|c|c|c|c|c|c|c|c|}
\hline Locality & $\begin{array}{l}\text { No. of } \\
\text { gardens } \\
\text { visited }\end{array}$ & $\begin{array}{l}\text { No. of gardens with } \\
\text { Arachnis Maggie Oei } \\
\text { (yellow ribbon) }\end{array}$ & $\begin{array}{l}\text { No. of gardens with } \\
\text { Arachnis Maggie Oei (red } \\
\text { ribbon) }\end{array}$ & $\begin{array}{l}\text { No. of gardens } \\
\text { with Bletilla } \\
\text { striata }\end{array}$ & $\begin{array}{l}\text { No. of } \\
\text { gardens with } \\
\text { Bletilla sp. }\end{array}$ & $\begin{array}{l}\text { No of gardens } \\
\text { with Vanda Miss } \\
\text { Joaquim }\end{array}$ & $\begin{array}{l}\text { No. of } \\
\text { gardens } \\
\text { without } \\
\text { orchids }\end{array}$ \\
\hline Bokwaongo & 10 & - & - & 03 & 02 & - & 07 \\
\hline Likoko & 15 & - & - & 06 & 02 & - & 09 \\
\hline $\begin{array}{l}\text { Clarks } \\
\text { quarters }\end{array}$ & 10 & - & - & 06 & 02 & - & 04 \\
\hline Mile 14 & 42 & 16 & 05 & 38 & 28 & 05 & 04 \\
\hline Mutengene & 15 & 04 & 02 & 11 & 10 & 01 & 04 \\
\hline Bwassa & 10 & 01 & - & 02 & 01 & - & 09 \\
\hline Sasse & 05 & - & - & 01 & - & - & 04 \\
\hline Total & 107 & 21 & 07 & 67 & 45 & 06 & 41 \\
\hline
\end{tabular}

mostly mixed with other flowers such as roses and offered as gifts (romantic offers), used in funerals, decorations during marriages, and bouquet for installations and awards ceremonies. In the flower market, orchids are second only to the roses in terms of prices and are always in limited supply.

In the MCR where cultivation takes place, the prices are lower compared to the flower market in Douala. An inflorescence of Arachnis is sold at 300 FCFA (\$ 0.5 US) to 500 (\$ 0.9US) FCFA during the flowering season. Flower pots of the species are prepared and sold at a cost 2.000 FCFA (\$3.57 US).

Vanda Miss Joaquim, Bletilla striata, and Bletilla sp. are not sold in the flower market in Douala but are of very high demand in the MCR. They are sold as entire potted plants (Fig. 4).

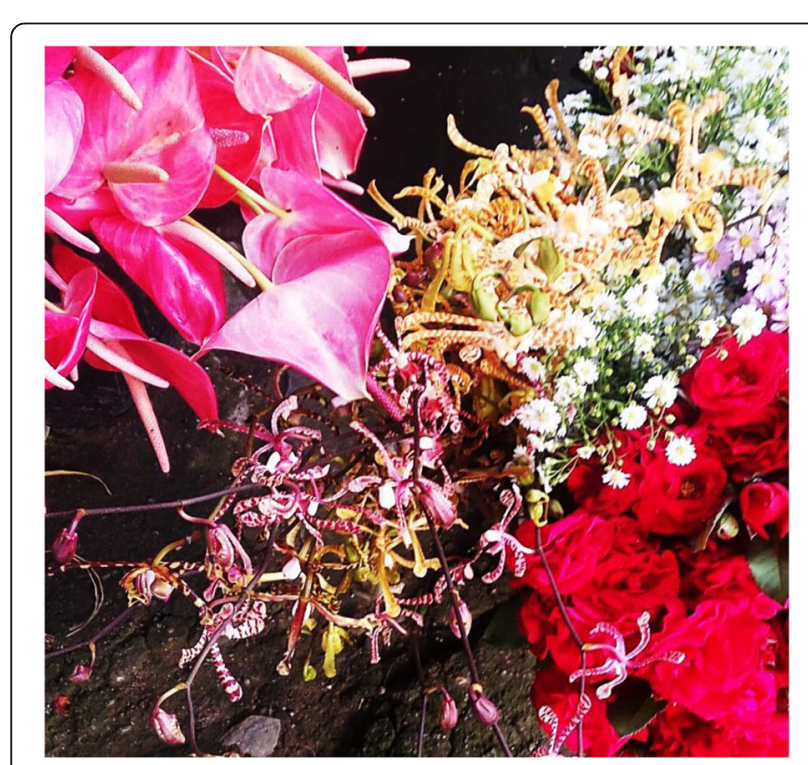

Fig. 3 Collection of orchids, roses, and Anthuriums sold at the Marché des fleurs in Douala
A pot of each species costs from 2.000 FCFA (\$3.57 US) to 3.500 FCFA ( $\$ 6.25$ US). A florist typically has as many as 100 pots of each species. Most buyers preferred Bletilla to Vanda Miss Joaquim, planting them as indoor or outdoor ornamentals in homes and hotels. A yearly sale from these potted orchids yields an approximated sum of 550.000 FCFA ( $\$ 1.339$ US) per farmer. These orchid species flower only once a year, and the flowering period of a single plant can last for $2-3$ months.

\section{Ethnobotany of orchids}

\section{Traditional use of orchids in the MCR}

Twenty-three orchids were found to be used in traditional medicine. Some were taken as decoction, concoction, or paste, while others were associated with magic (Table 3). The majority of species used as herbal

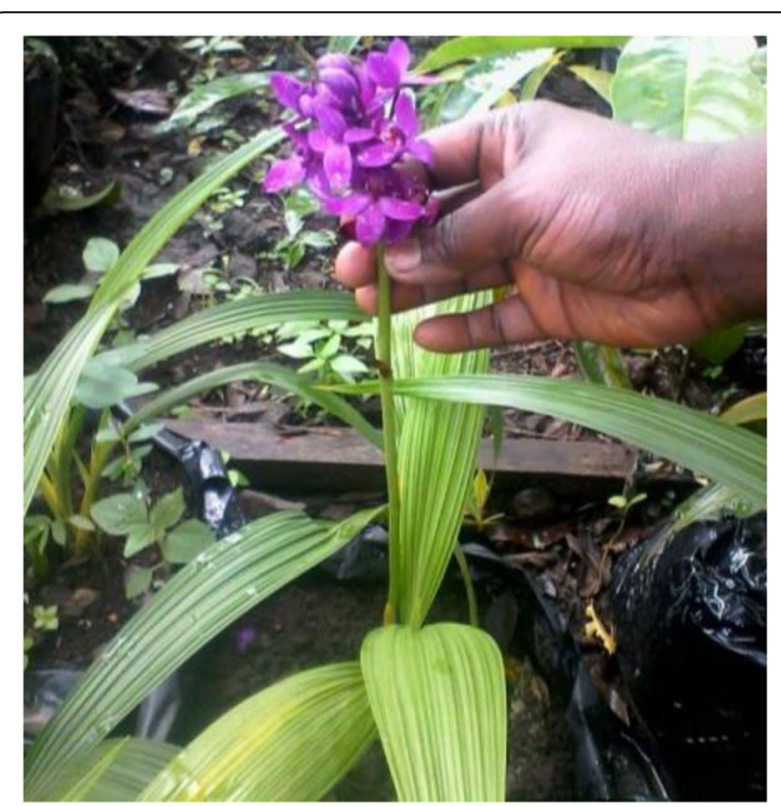

Fig. 4 Pot of Bletilla striata 
Table 3 Orchid species employed in herbal medicines in the MCR

\begin{tabular}{|c|c|c|c|c|c|c|c|}
\hline SN & Name of species & $\begin{array}{l}\text { Common } \\
\text { name }\end{array}$ & Use & $\begin{array}{l}\text { Mode of } \\
\text { application }\end{array}$ & $\begin{array}{l}\text { Plant part } \\
\text { used }\end{array}$ & Method of preparation & $\begin{array}{l}\text { No of } \\
\text { respondents }\end{array}$ \\
\hline \multirow[t]{11}{*}{1} & \multirow[t]{11}{*}{ Ansiella africana Lindl } & \multirow[t]{11}{*}{ Ewomboh } & Cough & Concoction & Pseudobulbs & Crush with leaves of Piper guinensis boil & 11 \\
\hline & & & \multirow[t]{2}{*}{ Madness } & \multirow[t]{2}{*}{ Concoction } & \multirow[t]{2}{*}{ Pseudobulbs } & $\begin{array}{l}\text { In combination with other herbs that were not given } \\
\text { is the main ingredient for the treatment of madness }\end{array}$ & \multirow[t]{2}{*}{08} \\
\hline & & & & & & Crush and boil & \\
\hline & & & \multirow[t]{2}{*}{ Diabetes } & \multirow[t]{2}{*}{ Decoction } & Roots & $\begin{array}{l}3 \text { leaves, } 10 \text { limes, and parasite boiled in } 5 \mathrm{~L} \text { of water } \\
\text { and consume every morning }\end{array}$ & 05 \\
\hline & & & & & Leaves & Crush with bitter cola (Garcinia kola) consume as tea & 08 \\
\hline & & & \multirow[t]{2}{*}{ Impotence } & \multirow[t]{2}{*}{ Concoction } & \multirow[t]{2}{*}{ Roots } & $\begin{array}{l}\text { Grind with dried seeds (7) of Piper guineense and } \\
\text { apply }\end{array}$ & \multirow[t]{2}{*}{10} \\
\hline & & & & & & Macerate leaves and apply before going to bed & \\
\hline & & & Side pain & Paste & Leaves & Paste act as short-term contraceptives & 15 \\
\hline & & & $\begin{array}{l}\text { Nightmares (bad } \\
\text { dreams) }\end{array}$ & Maceration & Leaves & Not specified & 02 \\
\hline & & & Pregnancy inhibitor & Paste & Pseudobulbs & & 05 \\
\hline & & & Love charms & $\begin{array}{l}\text { Not } \\
\text { specified }\end{array}$ & $\begin{array}{l}\text { Not } \\
\text { specified }\end{array}$ & & 08 \\
\hline \multirow[t]{3}{*}{2} & \multirow[t]{3}{*}{$\begin{array}{l}\text { Angraecum } \\
\text { augustipetallum Rendle }\end{array}$} & & Snake repellant & $\begin{array}{l}\text { Not } \\
\text { specified }\end{array}$ & Whole plant & Not specified & 0 \\
\hline & & & $\begin{array}{l}\text { Bone fortification in } \\
\text { children }\end{array}$ & Maceration & Leaf apex & Macerated leaves with kernel oil ("manyanga”) & 12 \\
\hline & & & Abortion & Concoction & Whole plant & Crush plant and boil & 04 \\
\hline \multirow[t]{2}{*}{3} & \multirow[t]{2}{*}{$\begin{array}{l}\text { Angraecum birrimense } \\
\text { Rolf }\end{array}$} & & Against sorcery & $\begin{array}{l}\text { Not } \\
\text { specified }\end{array}$ & Whole plant & Not specified & 04 \\
\hline & & & Snake repellant & $\begin{array}{l}\text { Not } \\
\text { specified }\end{array}$ & Whole plant & Not specified & 02 \\
\hline 4 & $\begin{array}{l}\text { Ancistrorhynchus seratus } \\
\text { Summerh }\end{array}$ & Koh & Diabetes & Tea & Leaves & Dried leaves & 06 \\
\hline 5 & $\begin{array}{l}\text { Bulbophyllum } \\
\text { melinostachyum Schltr. }\end{array}$ & & Anti-poisons & Powder & Whole plant & Grind dried leaves to powder and consume & 10 \\
\hline \multirow[t]{2}{*}{6} & \multirow{2}{*}{$\begin{array}{l}\text { Bulbophyllum } \\
\text { barbigerum Lindl. }\end{array}$} & & Side pain & Paste & Whole plant & Grind with dried seeds of Piper guinensis and apply & 12 \\
\hline & & & Ear pain & Decoction & Leaves & $\begin{array}{l}\text { Crush leaves with few drops of lemon or limes (stop } \\
\text { mucor). Drop in the infected ear }\end{array}$ & 07 \\
\hline 7 & $\begin{array}{l}\text { Bulbophyllum } \\
\text { intertextum Lindl. }\end{array}$ & Mpah & Side pain & $\begin{array}{l}\text { Paste } \\
\text { (smear) }\end{array}$ & Whole plant & Grind with dried seeds (7) of Piper guinensis and apply & 10 \\
\hline \multirow[t]{3}{*}{8} & \multirow[t]{3}{*}{$\begin{array}{l}\text { Bulbophylum lupulinum } \\
\text { Lindl. }\end{array}$} & \multirow[t]{9}{*}{ Etumukwoboh } & $\begin{array}{l}\text { Against sorcery } \\
\text { (protection) }\end{array}$ & $\begin{array}{l}\text { Planted } \\
\text { (not } \\
\text { exposed) }\end{array}$ & Whole plant & $\begin{array}{l}\text { Grown plants treated (sprinkled) once or twice a year } \\
\text { with blood of a roster accompanied with spoken } \\
\text { desires. }\end{array}$ & 07 \\
\hline & & & Night poisons & Concoction & Whole plant & Put a bottle of water and placed in the room & 03 \\
\hline & & & & & Whole plant & $\begin{array}{l}\text { Boil with } 7 \text { heads of Ageratum conyzoides and take as } \\
\text { tea }\end{array}$ & 05 \\
\hline \multirow[t]{3}{*}{9} & \multirow[t]{3}{*}{$\begin{array}{l}\text { Bulbophyllum } \\
\text { calyptratum Kraenzl }\end{array}$} & & $\begin{array}{l}\text { Skin diseases (measles, } \\
\text { poxes abscesses, } \\
\text { rashes) }\end{array}$ & Maceration & Leaves & $\begin{array}{l}\text { Macerate leaves with yellow stone and kernel oil, then } \\
\text { apply }\end{array}$ & 12 \\
\hline & & & Wounds & Decoction & Whole plant & Wash wounds with decoction & 06 \\
\hline & & & Burns & Paste & Whole plant & Apply paste on the burnt spot & 10 \\
\hline 10 & $\begin{array}{l}\text { Bulbophyllum simonii } \\
\text { Summerh }\end{array}$ & & Luck portion & Powder & Whole plant & Mix in body lotion and apply when need be & 06 \\
\hline \multirow[t]{2}{*}{11} & \multirow[t]{2}{*}{$\begin{array}{l}\text { Bulbophyllum falcatum } \\
\text { (Lindl.) Rchb.f. }\end{array}$} & & $\begin{array}{l}\text { Against thunder and } \\
\text { sorcery }\end{array}$ & $\begin{array}{l}\text { Not } \\
\text { specified }\end{array}$ & Whole plant & Grown in compound & 05 \\
\hline & & & Predictions & $\begin{array}{l}\text { Not } \\
\text { specified }\end{array}$ & Leaves & $\begin{array}{l}\text { Immediate necrosis young leave means not } \\
\text { embarking on a seriously planned journey }\end{array}$ & 07 \\
\hline 12 & $\begin{array}{l}\text { Bulbophyllum pumilum } \\
\text { (Swartz) Lindl. }\end{array}$ & Nnokoh & Epilepsy & Concoction & Whole plant & $\begin{array}{l}\text { Boil with leaves of Ageratum cornyzoides and Piper } \\
\text { guineensis take as bath and consume as tea }\end{array}$ & 05 \\
\hline \multirow[t]{2}{*}{13} & \multirow{2}{*}{$\begin{array}{l}\text { Calyptrochilum } \\
\text { emarginatum (Afzel.ex } \\
\text { Sw) Schltr. }\end{array}$} & & Charms & $\begin{array}{l}\text { Not } \\
\text { specified }\end{array}$ & Leaves & Not specified & 15 \\
\hline & & & Good luck & Power & Leaves & Make power out of Tapinanthus bangwensis and & 06 \\
\hline
\end{tabular}


Table 3 Orchid species employed in herbal medicines in the MCR (Continued)

\begin{tabular}{|c|c|c|c|c|c|c|c|}
\hline SN & Name of species & $\begin{array}{l}\text { Common } \\
\text { name }\end{array}$ & Use & $\begin{array}{l}\text { Mode of } \\
\text { application }\end{array}$ & $\begin{array}{l}\text { Plant part } \\
\text { used }\end{array}$ & Method of preparation & $\begin{array}{l}\text { No of } \\
\text { respondents }\end{array}$ \\
\hline & & & & & & orchids, mix with body lotion, and apply & \\
\hline \multirow[t]{3}{*}{14} & \multirow[t]{3}{*}{ Cyrtorchis acuata } & & Charms & Powder & Whole plant & Consume as tea & 07 \\
\hline & & & Diabetes & Infusion & Leaves & Dried leaves consume as tea & 04 \\
\hline & & & Skin diseases & Paste & Leaves & Mix a quantity at a time in body lotion and apply & 05 \\
\hline \multirow[t]{2}{*}{15} & \multirow{2}{*}{$\begin{array}{l}\text { Diaphananthe bidens } \\
\text { (Afzel ex Sw.) Schltr. }\end{array}$} & Mbingwoh & Fertility & Powder & Whole plant & Powder of plant mixed in milk act as an aphrodisiac & 03 \\
\hline & & & Diabetes & Concoction & Whole plant & Boiled mixture of orchid and Piper umbellatum & 08 \\
\hline \multirow[t]{3}{*}{16} & \multirow[t]{3}{*}{$\begin{array}{l}\text { Graphorkis laurida (Sw.) } \\
\text { Kuntze }\end{array}$} & Nkelenkwokwo & Coughs & Concoction & Whole plant & $\begin{array}{l}\text { Crush and boil with sweet alligator pepper (Piper } \\
\text { guinenses) and ginger }\end{array}$ & 13 \\
\hline & & & Tuberculosis & Powder & Whole plant & Mix powder with black palm kernel oil and consume & 09 \\
\hline & & & $\begin{array}{l}\text { Tooth maggot/tooth } \\
\text { aches }\end{array}$ & Concoction & Whole plant & Crush and boil with back of pear & 07 \\
\hline \multirow[t]{3}{*}{17} & \multirow[t]{3}{*}{$\begin{array}{l}\text { Habenaria procera } \\
\text { (Afzel. ex Sw.) Lindl. }\end{array}$} & Ekuh & Blood purification & Powder & Whole plant & $\begin{array}{l}\text { Dried leaves of plants are ground and consumed at } \\
\text { such or mixed with lemon and taken as tea }\end{array}$ & 12 \\
\hline & & & $\begin{array}{l}\text { Gastritis (chest and } \\
\text { stomach pains) }\end{array}$ & Concoction & Whole plant & Plants boiled with leaves of Piper guinensis & 05 \\
\hline & & & Arthritis & Decoction & Pseudobulbs & $\begin{array}{l}\text { Cush, boil and consume. Also massage body with } \\
\text { crushed substance }\end{array}$ & 10 \\
\hline \multirow[t]{3}{*}{18} & \multirow{3}{*}{$\begin{array}{l}\text { Liparis nervosa (Thunb.) } \\
\text { Lindl. }\end{array}$} & & Burns & Paste & Entire plants & Crush and apply to spot & 15 \\
\hline & & & Ulcers & Concoction & Whole plant & $\begin{array}{l}\text { Boil with Bidens pilosa and leaves of Piper guineense, } \\
\text { take as tea }\end{array}$ & 08 \\
\hline & & & Stomach aches & Powder & Whole plant & Consume as tea & 10 \\
\hline \multirow[t]{2}{*}{19} & \multirow{2}{*}{$\begin{array}{l}\text { Listrostachys pertusa } \\
\text { (Lindl.) Rchb.f. }\end{array}$} & & Measles & Concoction & Whole plant & Crush and boil take as purgative & 05 \\
\hline & & & Constipation & Powder & Whole plant & Consume as tea & 04 \\
\hline 20 & $\begin{array}{l}\text { Polystachya concreta } \\
\text { (Jacq.) Garay \& } \\
\text { H.R.Sweet }\end{array}$ & & Rheumatism Arthritis & $\begin{array}{l}\text { Not } \\
\text { specified }\end{array}$ & $\begin{array}{l}\text { Not } \\
\text { specified }\end{array}$ & Not specified & 01 \\
\hline \multirow[t]{2}{*}{21} & \multirow{2}{*}{$\begin{array}{l}\text { Polystachya cultriformis } \\
\text { (Thouars) Lindl. ex } \\
\text { Speng. }\end{array}$} & Neshieh & Measles & Concoction & Whole plant & $\begin{array}{l}\text { Boil plants with mistletoes (Tapinanthus bangwensis) } \\
\text { and limes }\end{array}$ & 05 \\
\hline & & & Burns & Paste & Leaves & Grind leaves with seeds of Piper guineense and apply & 04 \\
\hline 22 & $\begin{array}{l}\text { Polystachya caloglossa } \\
\text { Rchb.f. }\end{array}$ & Ntohpoupou & Rheumatism & $\begin{array}{l}\text { Not } \\
\text { specified }\end{array}$ & $\begin{array}{l}\text { Not } \\
\text { specified }\end{array}$ & Not specified & 02 \\
\hline 23 & $\begin{array}{l}\text { Tridactyle tridactylites } \\
\text { (Rolfe) Schltr. }\end{array}$ & & Madness & Concoction & Whole plant & Not specified & 03 \\
\hline
\end{tabular}

medicines in the MCR were from the following genera: Angraecum, Ansellia, Bulbophyllum, Liparis, Habenaria, Graphorkis, and Polystachya. Traditional healers did however not specify how orchids were prepared for charms. Ansellia africana was especially frequently used as herbal medicine. The usage of bulbs was mostly associated with sorcery and for external application. All the orchids used medicinally are obtained only from the wild.

Species with the highest cultural importance index (CI) were Ansiella africana, Liparis nervosa, and Graphorkis laurida (Fig. 5). Those with the least cultural importance index were Angraecum birrimense, Bulbophyllum pumilum, and Tradactyle tridactylites.

Overall on average, the CI for all orchid species with ethnobotanical uses in the MCR, the ethnobotanical richness, was 6.86. This could be used as a standard for a comparative study of different medicinal plant species of the MCR or could also be used for same species in a different area.

Figure 6 further shows the relative importance index (RI) and the relative use index (RNU) of orchid species. $A$. africana had the highest RI and RNU, while Chameangis emarginatum, B. melinostachyum, and B. intertextum had high RI but very low RNU.

Most medicinal orchids were used for clairvoyance, highly associated with myths or folklore, and also for external application to cure skin-related diseases as well as for pains (Fig. 7). The least frequent uses were for epilepsy and psychological problems. Only one species (Bulbophyllum pumilum) was known to be used as a curative agent for epilepsy.

\section{Discussion}

The purpose of this study was to elucidate the ethnobotanical uses of orchids in the MCR and to 

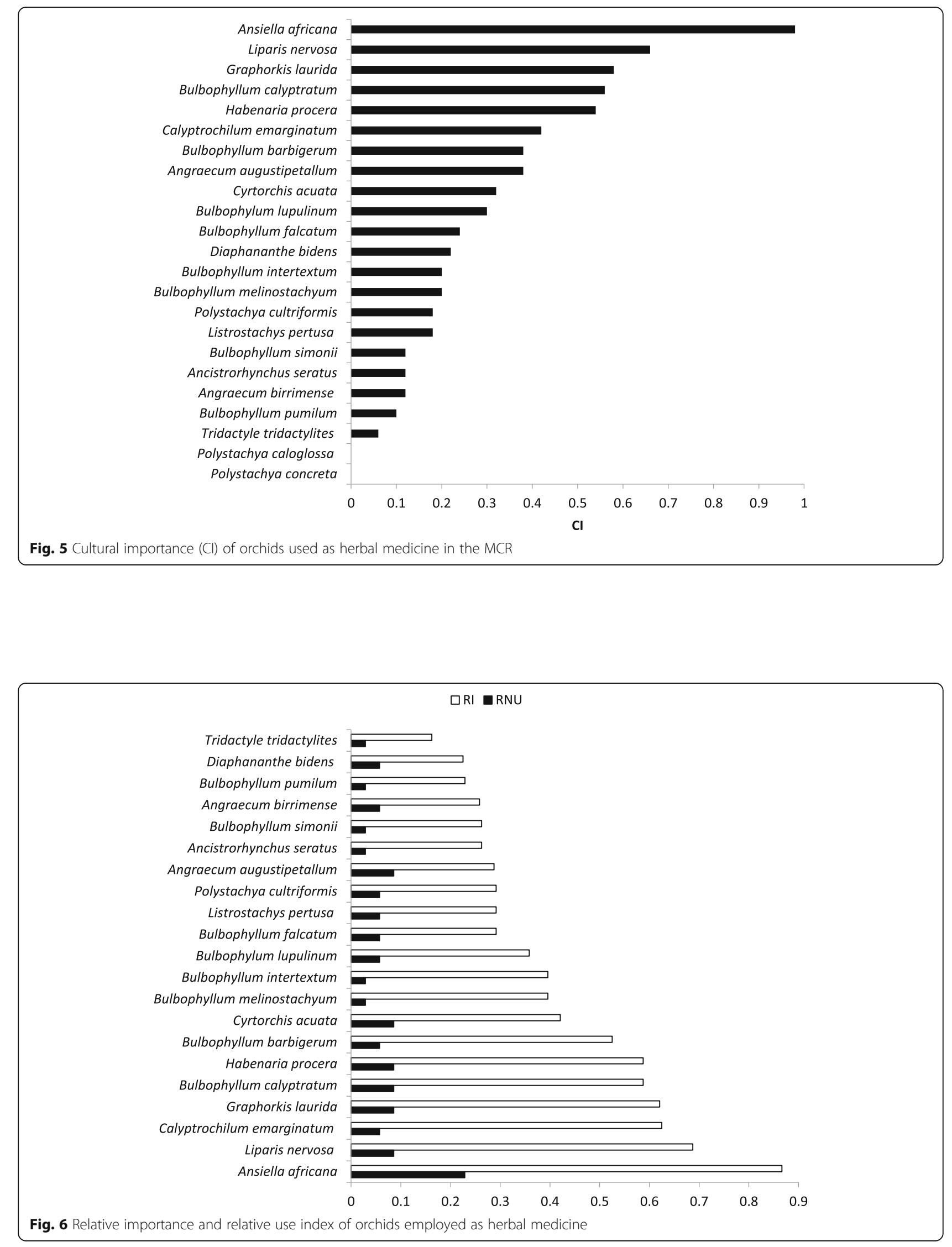


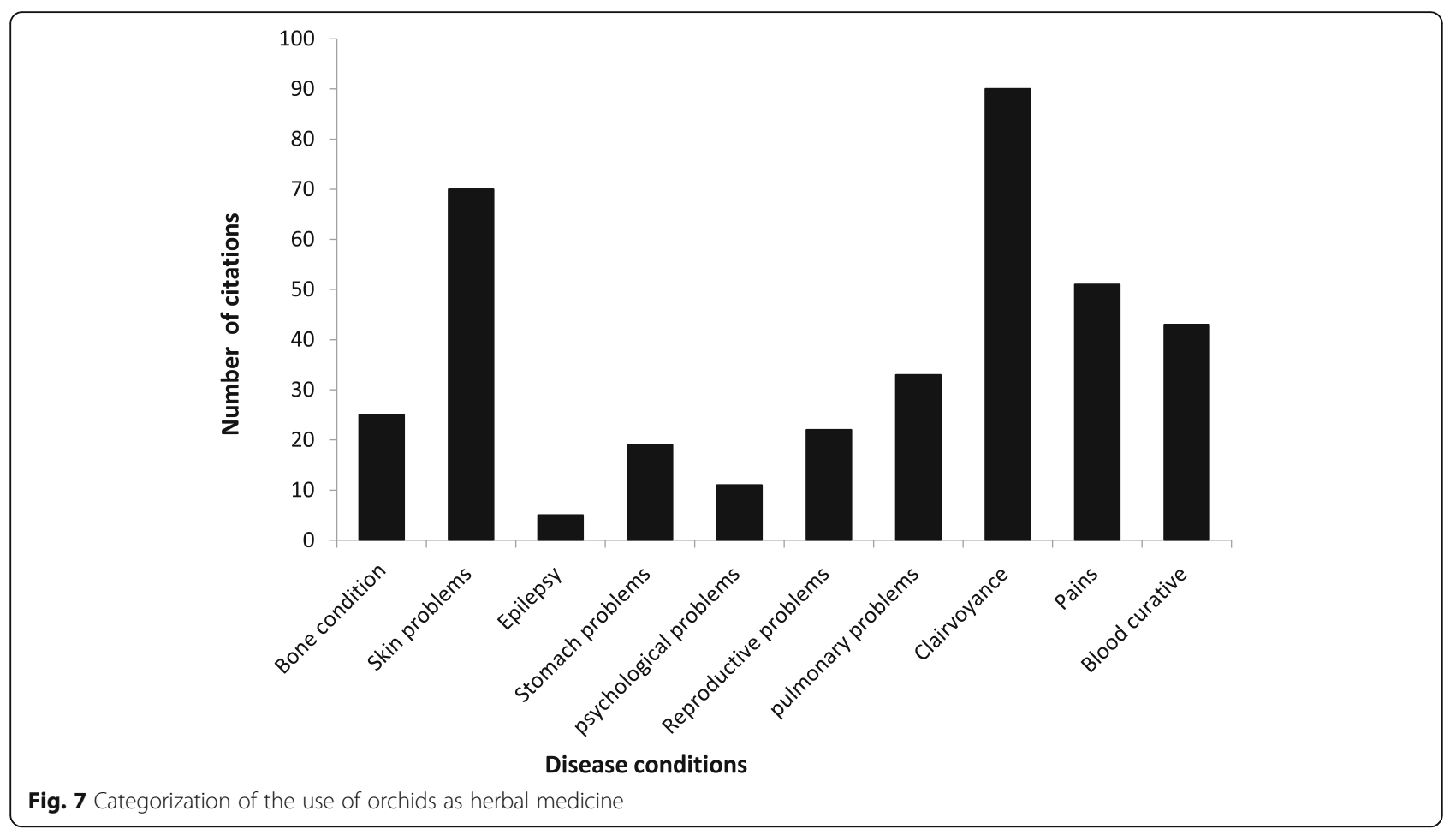

complement ongoing efforts for their conservation. Most of the orchids not only had ethnomedicinal uses, esthetic uses, and mystical uses, but also fetched appreciable incomes for traders in orchids as ornamentals. Several authors have found uses for orchids similar to those reported in this study. An example is Bletilla striata, an important medicinal orchid, which is reported to have been used in treating wounds in China for over 1500 years [20]; [21]. The pseudobulb is reported to have antibacterial, anti-inflammatory, antiphlogistic, demulcent, styptic, and vulnerary properties [22]; [8]. It is taken internally in the treatment of hemorrhages of the stomach or lungs, uterine bleeding, and nose bleeds and is said to be effective against the endotoxin produced by Haemophilus pertussis in whooping coughs.

\section{International versus national trade of orchids}

The rich horticultural values attributed to orchids in the international markets cannot be compared with those of the national flower market in Cameroon, as the "flower culture" is still developing in the country. Many people often prefer synthetic to natural flowers. Although natural flowers are beautiful with a pleasant fragrance, they do have a limited lifespan and cannot last up to a year, unlike synthetic flowers which can last for more than a year. Secondly, natural flowers are comparatively expensive.

Orchids earn a reduced price in Cameroon compared to values obtained in the international markets. A single pot of Vanda Miss Joaquim, Bletilla striata, and Bletilla sp. in flower gardens of the MCR was sold at 3.000 to
3.500 FCFA (6 to7 $\$$ ). According to information from Toh Garden [23], Vanda Miss Joaquim was sold at \$25 US (approximately 15.000 FCFA) in international trade; Bletilla striata at \$17US (9.000 FCFA) [24], while the Arachnis species were sold on average at \$28.95 US [25]. However, orchid traded as ornamentals do have a large local economic impact, and the income is used to buy land, build houses, cover education expenses, and provide for other needs of the orchid-trading families.

\section{Species with medicinal uses in the MCR}

The use of wild species of medicinal orchids seems to be of great economic importance across the developing world. Bulpit [26] reported the use of Cyrtorchis arcuate in China; with a similar method of preparation (pounded into a powder) employed in promoting friendship, consistent with its use as a charm in the MCR. It is also reportedly used for treating diabetes and skin infections which is consistent with findings of the current study. Also, Tridactyle tricuspis was reported to be used in curing madness [26]; in the MCR, species that were used for the same purpose were Tridactyle tridactylites and Ansiella africana. Our results are consistent with other studies that found medicinal uses for orchids, for instance, Linthoingambi et al. [27], Subedi et al. [28], and Pant [1] reported the use of the tubers of Habenaria for blood purification and the cure for leprosy, unconsciousness, and youthfulness and to increase vigor and Liparis sp. for treatment of burns, cancerous ulcers, and gangrene. 
Dash et al. [29] and Teoh [28] reported the use of Polystachya concreta for the cure of arthritis. Similar results were obtained in the present study. Many authors [29-34] found Ansiella africana used as charms and antidotes for nightmares, similar to our own results. For such species, the traditional doctors and herbalists interviewed typically do not provide methods of preparation. Love charms have been used extensively in African traditional culture. Some species encountered in this study have similar uses elsewhere, for example, the roots of $A$. africana are prepared as an infusion and administered as an emetic [35], while the leaves of the same species are used by men as a courting charm [36]. This species was reported by Hulmes [37] as a key ingredient in an emetic that is administered by a man to a young lady to make her love him. Species of Liparis are used as love or good luck charms though the parts used were not specified [36]. On a specific note, charms are prepared to either prevent or promote fertility. Ansiella africana is reportedly used by young men to prevent women from having children if their love is not returned [38]. Protective charms may be used for bad dreams, to ward off evil, to protect one from lightning strikes, and to protect the home. Ansiella africana leaves are prepared as an infusion to treat persons experiencing bad dreams [36]. Alternatively, one can inhale the smoke of its burning roots for the same purpose [36]. The tubers of certain orchids are used as an infusion that is sprinkled around the home to ward off evil. Whole plant decoctions of unspecified Habenaria species are ingested by couples to ensure the birth of a son [37].

\section{Conclusion}

Three orchid species and another identified to generic levels were of horticultural importance in the MCR. They include Papilionanthe teres $\times$ Papilionanthe hookeriana, Arachnis hookeriana var. luteola $\times$ Arachnis flos-aeris var. gracilis, Bletilla striata, and another member of the genus Bletilla. In addition, 23 species of orchids were of ethnomedicinal importance, useful in treating ailments from coughs to various pains. These results are significant as they expose the hidden potentials of orchids of the MCR and provide an added incentive for the conservation of orchids of the region. Sustainable conservation that takes into consideration the ethnobotanic and socioeconomic uses of the species represents a plus-plus approach and would thus be more effective.

\section{Acknowledgements}

The authors thank the horticulturist in the Mount Cameroon Region and traders in orchids for participating in this study. We also thank the field guides who assisted in navigating the mountain sites.

\section{Authors' contributions}

BAF, SEE, and TEB conceived the research and drafted the Manuscript. SEE, BDA, and EMA collected the field and socioeconomic data. PTT and YA conducted the data analyses and interpretation. All authors reviewed the draft manuscript and approved it for submission.

\section{Funding}

This research was not funded.

Availability of data and materials

All data relevant to understanding the results of this study have been included in the manuscript.

\section{Ethics approval and consent to participate}

This research was approved by the University of Buea Ethics Committee. Socioeconomic data was collected after duly obtaining Informed Consent of the respondents. Prior Informed Consent is sought from respondents to a study by explaining the purpose for the study, the personal liabilities of both the researcher and the respondent, and that the respondents can only participate willingly, retaining the right to withdraw from the study at any point is they so choose. This is done prior to each interview. It can be obtained orally as in this study, or using an Informed Consent Form that is filled in by each respondent.

\section{Consent for publication}

Not applicable

\section{Competing interests}

The authors declare that they have no competing interests.

\section{Author details}

${ }^{1}$ Department of Botany and Plant Physiology, Faculty of Science, University of Buea, P.O. Box 63, Buea, Cameroon. ${ }^{2}$ Department of Agriculture, Higher Technical Teachers' Training College Kumba, University of Buea, P.O Box 63, Buea, Cameroon. ${ }^{3}$ Douala, Cameroon.

Received: 21 September 2018 Accepted: 24 May 2019

Published online: 25 June 2019

References

1. Pant B. Medicinal orchids and their uses: tissue culture a potential alternative for conservation. African J Plant Sci. 2013;7(10):448-67.

2. Joshi G, Tewari LM, Lohani N, Upreti K, Jalal JS, Tewari G. Diversity of orchids on Uttarakhand and their conservation strategy with special reference to their medicinal importance. Rep Opin. 2009;1:47-52.

3. Hew CS, Arditti J, Lin WS. Orchid cut-flower production in ASEAN countries. In: Arditti, J Editors Orchid Biol Rev Perspect 1997. 6:363-401.

4. Kasulo V, Mwabumba L, Munthali C. A review of edible orchids in Malawi. J Hortic For. 2009;1:133-9.

5. Stewart J, Griffith M. Manual of orchids. Oregon: Timber Press Portland; 1995.

6. Gutierrez RMP. Orchids: a review of uses in traditional medicine, its phytochemistry and pharmacology. J Med Plant Res. 2010;4(8):592-638.

7. Cable S, Cheek M. The plants of Mount Cameroon: a conservation checklist. London: Royal Botanic Gardens Kew; 1998.

8. Stuart GA. Chinese Materia Medica Taipei, Southern Materials Centre. A translation of an ancient Chinese herbal; 1984

9. Singh A, Duggal S. Medicinal orchids: an overview. Ethnobotanical Leaflets. 2009;13:351-63.

10. Szlachetko D. Genera et species Orchidalium 1. Polish Bot J. 2001:46:11-26.

11. Chinsamy M, Finnie JF, Van Staden J. The ethnobotany of South African medicinal orchids. S Afr J Bot. 2011:77:2-9.

12. Focho DA, Fonge BA, AGN F, Essomo SE. A study of the distribution and diversity of the family Orchidaceae on some selected lava flows of Mount Cameroon. Afr J Environ Sci Technol. 2010;4(5):263-73.

13. Simo M, Droissart V, Sonke B, Stevart T. The orchid flora of the Mbam Minkom Hills (Yaounde, Cameroon). Belg J Bot. 2009;142(2):111-23.

14. Bussmann RW. Vegetation zonation and nomenclature of African Mountains-an overview. Lyonia. 2006;11:41-66.

15. Suh CE, Sparks RSJ, Fitton JG, Ayonghe SN, Annen C, Nana R, Luckman A. The 1999 and 2000 eruptions of Mt. Cameroon; eruption, behaviour and petrochemistry of lava. Bull Volcanicity. 2003;65:267-81.

16. Tchouto P. Forest inventory report of the proposed Etinde rainforest reserve. Limbe: Mount Cameroon Project; 1996. 
17. Fonge BA, Yinda GS, Focho DA, Fongod AGN, Bussmann RW. Vegetation and soil status on an 80-year-old lava flow of Mt. Cameroon, West Africa. Lyonia. 2005;8:17-39.

18. Signorini AM, Piredda M, Bruschi P. Plants and traditional knowledge: an ethnobotanical investigation on Monte Ortobene (Nuoro, Sardinia). J Ethnobiol Ethnomed. 2009;5:6.

19. Sharma M, Sharma CL, Debberma J. Ethonobotanical studies of some plants used by Tripuri tribe of Tripura NE INDIA with special reference to Magico religious beliefs. Int J Plant Anim Environ Sci. 2014;4(3):518-28.

20. Bown D. Encyclopaedia of herbs and their uses. London: Dorling Kindersley; 1995.

21. Bown D. The royal horticultural society new encyclopedia of herbs \& their uses. London: Dorling Kindersley; 2002.

22. Yeung HC. Handbook of Chinese herbs and formulas, vol. 1985. Los Angeles: Institute of Chinese Medicine; 1985. p. 125.

23. Toh Gardens. Quality orchid grower gift shop Singapore. 2017.

24. Plant Delight Nursery Inc. Singapore: Juniper level botanic garden; 2017.

25. Seattle Orchids. My orchid rewards, gift shop and wholesale of orchids. 2017. http://www.seattleorchids.com. Accessed 25 Mar 2017.

26. Bulpit CJ. The use and misuse of orchids in medicine. QMJ: An Int J Med. 2005;98(5):625-31.

27. Linthoingambi L, Das AK, Singh PK, Ghosh SK. Medicinal uses of orchid by tribes in India: a review. Int J Curr Res. 2013:5(10):2796-8.

28. Subedi A, Kunwar B, Choi Y, Dai Y, Andel T, Chaudhary R, Boer H, Gravendeel B. Collection and trade of wild-harvested orchids in Nepal. J Ethnobiol Ethnomed. 2013;9:64-72.

29. Dash PK, Sahoo S, Bal S. Ethnobotanical studies on orchids of Niyamgiri Hill Ranges, Orissa, India. Ethnobotanical Leaflets. 2008;12:70-8.

30. Teoh SE. Medicinal orchids of Asia, herbal usage. Switzerland: Springer; 2016.

31. Batten A, Bokelmann H. Wild flowers of the Eastern Cape Province. Cape Town: Cape \& Transvaal Printers; 1966.

32. Stewart J, Linder HP, Schelpe EA, Hall AV. Wild orchids of South Africa. Cape Town: Macmillan; 1982.

33. Pooley E. A field guide to wild flowers of KwaZulu-Natal and the eastern region. Durban: Natal Flora publications trust; 1998.

34. Leistner OA, editor. Seed plants of southern Africa: families and genera. Strelitzia 10. Pretoria: National Botanical Institute; 2000.

35. Nichols G. Indigenous Plant of the month. The grapevine; 2002. p. 76.

36. Crook V. Ansellia africana. In: The IUCN red list of threatened species. IUCN. 2013: https://www.iucnredlist.org/species/44392142/44437667. Accessed 18 June 2019.

37. Hulme MM. Wild flowers of natal Pietermaritzburg: Schuter and Shooter; 1954.

38. Watt JM, Breyer-Brandwijk MG. The medicinal and poisonous plants of southern and eastern Africa. 2nd ed. Edinburgh: E\&S Livingstone; 1962

\section{Publisher's Note}

Springer Nature remains neutral with regard to jurisdictional claims in published maps and institutional affiliations.

\section{Ready to submit your research? Choose BMC and benefit from:}

- fast, convenient online submission

- thorough peer review by experienced researchers in your field

- rapid publication on acceptance

- support for research data, including large and complex data types

- gold Open Access which fosters wider collaboration and increased citations

- maximum visibility for your research: over $100 \mathrm{M}$ website views per year

At BMC, research is always in progress.

Learn more biomedcentral.com/submissions 